\title{
Penal Mediation as the Concept of Restorative Justice in the Draft Criminal Procedure Code
}

\author{
Emmanuel Ariananto Waluyo Adi \\ Deputy for Maritime Affairs and Investment, Cabinet Secretariat of the Republic of Indonesia, Jakarta, \\ Indonesia \\ Email: eadiwaluyo@gmail.com \\ ORCID Link: https://orcid.org/0000-0002-1987-9700
}

\section{Citation:}

Adi, E. A. W. (2021). Penal Mediation as the Concept of Restorative Justice in the Draft Criminal Procedure Code. Lex Scientia Law Review, 5(1), 139-164, doi: https://doi.org/10.1 5294/lesrev.v5i1.46704

\section{History of Article}

Received: May 4, 2021

Revised: May 17, 2021

Accepted: May 27, 2021

(C) The Author(s)

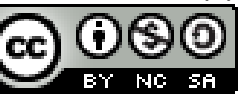

This work is licensed under a Creative Commons Attribution-NonCommercialShareAlike 4.0 International License. All writings published in this journal are personal views of the authors and do not represent the views of this journal and the author's affiliated institutions.

Lex Scientia Law Review published by Faculty of Law, Universitas Negeri Semarang, Indonesia in collaboration of UKM Lex Scientia. Published biannually every May and November.

\begin{abstract}
The law recognizes both litigation and non-litigation settlement mechanisms, but it is almost not explicitly regulated for non-litigation settlement in criminal cases. Non-litigation in criminal recognizes the concept of restorative justice for the public interest, which is different from the private realm in civil. The concept of restorative justice exists to rehabilitate the state of criminals so that they are accepted back into the community. The concept of restorative justice is manifested in the mediation mechanism in criminal law in the form of penal mediation, but penal mediation does not yet have a legal umbrella. The non-progressive normative application of the law results in the overcapacity of prisons/remand centres. Currently, the Draft Criminal Procedure Code (hereinafter as RKUHAP) is being drafted, which does not yet regulate the application of non-litigation solutions. Later, it can be applied by law enforcement agencies so that problems such as overcapacity prisons are resolved and the creation of peaceful order in the community. This study aims to provide a view of the concept of penal mediation in criminal procedural law to serve as an aspiration for the consideration of the parties involved in the preparation of the substance of the RKUHAP. This paper uses a normative approach with technical analysis using hermeneutic analysis and interpretation methods.
\end{abstract}




\section{KEYWORDS}

Penal Mediation; Restorative Justice; RKUHAP.

\section{INTRODUCTION}

Law exists to create order and peace in society as well as in criminal law regulating legal relations between the state (legal apparatus) and individuals (society) on a matter of public interest (public law) which essentially aims to create such prosperity and peace. So far, criminal law is carried out normatively and processed conventionally, namely always through court channels, even though criminal law is an ultimum remedium (a final measure) when there is a non-litigation settlement option in the form of mediation which generally exists in civil law. However, in essence, it can be applied in law. Crimes related to the purpose of restoring/restoring criminal offenders later in the community are based on the concept of restorative justice as outlined in substance in the penal mediation mechanism-examples of its application in cases of minors, Domestic Violence (hereinafter as KDRT), Copyrights, and Patents. Based on data from the Supreme Court up to May 2021, the Supreme Court has processed 580,518 general criminal cases with 23,750 decisions on general criminal cases. ${ }^{1}$ It shows that many criminal cases have not been completed due to too many cases that have been resolved by litigation, even though they can be resolved through non-litigation channels. In the end, justice for the victims and perpetrators is still unclear. The application of criminal law has not yet produced a deterrent effect. It can be seen in the latest example in 2020, namely that some prisoners who were released during the pandemic of the coronavirus outbreak (covid-19) committed criminal acts again, such as theft, physical violence, etc., which actually added to unrest in public. ${ }^{2}$ Alternatively, in the case of someone stealing rice during the Large-Scale Social Restriction of the Covid-19 pandemic because they do not have money, if the legal apparatus sees it normatively, it clearly fulfills the element of theft in the Criminal Code (hereinafter as KUHP), but if he is imprisoned will solve the problem the root which if resolved does not reach the root will later emerge the same perpetrators. The settlement always repeats itself through imprisonment, is not that criminal law exists to create peace, security, and prosperity. However, for whom it really is and whether it has achieved true justice.

\footnotetext{
${ }^{1}$ Directory of Supreme Court Decisions, accessed from https://putusan3.mahkamahagung.go.id/dirdir/index/kategories/pidana-umum-

2 Audrey Santoso, "27 Napi Berulah Lagi Setelah Dibebaskan, Kabareskrim: Sanksi Lebih Berat", Detik, April 21, 2020, accessed from https://news.detik.com/berita/d-4984907/27-napi-berulah-lagi-setelahdibebaskan-kabareskrim-sanksi-lebih-berat/2.
} 
In responding to crimes deemed to be restored, as mentioned above, there is a punishment paradigm known as restorative justice. The perpetrator is encouraged to repair the harm caused to the victim, his family, and the community.

Based on data from the Directorate General of Corrections, the capacity of prisons throughout Indonesia in 2019 is around 125 thousand people, but the realization is that they are inhabited by 249 thousand prisoners or overcapacity of $99 \% .^{3}$ This condition has resulted in various problems downstream, such as riots and cases of flight of inmates and detainees due to inadequate supervision due to the imbalance of the number of correctional officers / correctional officers with prisoners/detention residents even though the resolution should focus on problems upstream or the process before the entry of the prisoners. The prisoner is put in prison. The impact of this overcapacity can be seen in the case of the Class II B Siak Sri Indrapura Detention Center in Siak Regency, Riau Province, which experienced a riot which resulted in the burning of the detention center building on Saturday, May 11, 2019, Minister of Law and Human Rights. ${ }^{4}$ It clearly shows that Indonesian prisons/remand centers have been overcrowded. The settlement of Indonesian criminal cases does not go according to the spirit of criminal law when other countries have empty prisons, for example, the Netherlands focuses on efforts to deal with crime with rehabilitation rather than putting people in iron cages because the results are more effective and cost-effective prison administration which proved to be more expensive. ${ }^{5}$ It shows that other countries can implement and succeed in restoring criminals, and why can't Indonesia? It is known that the concept of penal mediation has not been regulated in the provisions of criminal law. However, the effectiveness of settlement through penal mediation in Indonesia can be seen in 2019 Kulonprogo Sector Police Resort Galur Sector can resolve debts and fraud cases by mediation. ${ }^{6}$ Moreover, in 2015-2017, the Telaga Sector Police, together with Mongolato Village Officials, Gorontalo jointly resolved 18 types

\footnotetext{
${ }^{3}$ Victorio H. Situmorang, "Lembaga Pemasyarakatan Sebagai Bagian Dari Penegakan Hukum", Jurnal Pusat Pengkajian dan Pengembangan Kebijakan Badan Penelitian dan Pengembangan Hukum dan HAM Kementerian Hukum dan HAM RI, Volume 13 Number 1, 2019, p. 90.

${ }^{4}$ Marfuatul Latifah, "Overcrowded Pada Rumah Tahanan Dan Lembaga Pemasyarakatan Di Indonesia: Dampak Dan Solusinya, Info Singkat", Pusat Penelitian Badan Keahlian DPR RI, Volume XI, No. 10 / II / Puslit / May / 2019, p. 2.

5 Absal Bachtiar, "Mengapa Belanda Kekurangan Narapidana", Kumparan, November 9, 2018, accessed from https://kumparan.com/absal-bachtiar/mengapa-belanda-kekurang-narapidana1541777778863219334.

6 Priyo Santoso, "Diskresi Kepolisian Melalui Mediasi Penal (Studi Kasus di Polsek Galur, Kulonprogo)", Jurnal Penegakan Hukum dan Keadilan, Volume 1 Number 2, 2020, p. 102.
} 
of criminal acts ( 6 cases of domestic violence, 5 cases of maltreatment, 3 cases of defamation, 3 cases of traffic accidents) through mediation penal. ${ }^{7}$ If it is not regulated, it is effective. What if it is regulated in the provisions of the criminal procedure law later, which of course, will get better in settlement of criminal cases.

The concept of restorative justice as outlined in the penal mediation mechanism is included in the practice of the fourth principle of Pancasila, namely "Democracy Led by Wisdom in Deliberation and Representation," this principle teaches us to make choices through deliberation, prioritizing deliberation in making decisions for the common interest. It is adopted in settlement of a criminal case, the process needs to be considered wisely, and deliberation is also the original culture of the Indonesian people so that it is applied to resolve a conflict that does not yet have a solid legal umbrella. Therefore, penal mediation is a solution to reduce the volume of cases, as long as it is desired by the parties (suspects and victims) and maintains social harmony. The people's interest in realizing the general welfare is essential in determining the priority bills to be discussed. Bills that are in direct contact with the protection of people's rights and welfare should be a top priority for discussion and ratification. The public wants laws and regulations to be able to create justice, order, and welfare as reflected in the values of Pancasila and the 1945 Constitution of Republic Indonesia (hereinafter as UUD NRI 1945). Considering that one of the goals of the nation/state is to advance the general welfare, it is necessary to achieve this goal. Bills that are in direct contact with the protection of people's rights and welfare should be a top priority for discussion and ratification. Considering that one of the goals of the nation/state is to advance the general welfare, it is necessary to achieve this goal.

Currently, a Working Meeting of the Legislation Body of the House of Representatives of the Republic of Indonesia has been held with the Minister of Law and Human Rights of the Republic of Indonesia and the Law Drafting Committee of the Regional Representative Council of the Republic of Indonesia in order to improve the 2021 Priority Bill National Legislation Program and amend the National Legislation Program for the Bill 2020-2024, agreed to agree on a total of 246 Bill Prolegnas Amendments for 2020-2024 in which there is a Draft Law on Amendments to Law Number 8 of 1981 concerning RKUHAP. The current KUHAP was drafted when Indonesia was colonized by the Dutch long ago. Many of its applications were not in line

\footnotetext{
7 Arpin \& Haritsa, "Penyelesaian Tindak Pidana Melalui Mediasi Penal Oleh Masyarakat Desa Di Kabupaten Gorontalo", Jurnal Jurisprudentie, Volume 5 Number 2, 2018.
} 
with the noble values and customs of the Indonesian people and the dynamics of technology and information development in today's society.

Based on the description of this background, several problem formulations can be drawn as a focus in conducting the discussion, namely, how is the application of the concept of restorative justice in Indonesia? and how is the application of penal mediation in the settlement of criminal cases in Indonesia today? Through this formulation, this paper is proposed as a description of a systematic and comprehensive solution to answer problems that may be an option for better justice in Indonesian Criminal Procedure Law in the future.

\section{METHOD}

This paper uses a normative approach that not only examines the law in the sense of statutory regulations but includes a broader aspect, namely something that can be traced through literature. The analysis technique used in this research is the hermeneutic analysis method and interpretation. The hermeneutic analysis is used to understand the text as a series of signs that are arranged in a certain way by the author to convey particular meanings. In contrast, interpretation analysis is used to interpret and reveal the ontological, epistemological, and axiological essence associated with the purpose of this study.

\section{RESULT AND DISCUSSION}

\section{A. Restorative Justice on Progressive Criminal Procedure Code}

Modern criminal justice, which prioritizes the personal maker as a human being rather than acting as an act that is against the law alone, does not only see the violation of the law as a social symptom. ${ }^{8}$ Soekanto said that law enforcement does not merely mean the implementation of laws. However, law enforcement is an activity to harmonize the relationship of values outlined in principles that aim to create, maintain and maintain peace. ${ }^{9}$ In this case, it can be seen that it is necessary to see a criminal offense from the point of view of the perpetrator as part of society as well. There are expert opinions that support this, such as Van Hattum said in his translation, namely that criminal law today has only reached a particular stage in its history of growth,

\footnotetext{
8 Utrecht, Hukum Pidana I, Pustaka Tinta Mas, Surabaya, 1994, p. 114.

${ }^{9}$ M. Iksan Sudaryono \& Kuswardani, "Model Penyelesaian Secara Alternatif Dalam Peradilan Pidana (Studi Khusus Terhadap Model Penyelesaian Perkara Pidana Oleh Lembaga Kepolisian)", Jurnal Penelitian Humaniora, Volume 13 Number 1, 2012, p. 62-73.
} 
even though the final point has clearly not been reached. ${ }^{10}$ Then Andi Hamzah said that the ultimate goal of criminal law is to achieve order, tranquility, peace, justice, and prosperity in society. Bambang Poernomo said that the aim of criminal law in terms of theory is paralleled with the law in general, namely to achieve "peace" in society. Furthermore, in the operationalization of the objective of the criminal law, from a practical point of view, it is to obtain a reality that "has succeeded in reducing unrest in society in the form of rational and constructive social action based on legal truth and legal justice."11

The objectives of criminal procedure law in the guidelines for implementing the Criminal Procedure Code are:

1. Seeking and obtaining or at least approaching material truth is the complete truth of a criminal case by applying the provisions of the criminal procedure law honestly and precisely.

2. Looking for the perpetrators who can be charged with violating the law and then requesting an examination and decision from the court to determine whether it is proven that a crime has been committed and determine whether it is proven that a criminal act has been committed and whether the person accused can be guilty.

3. After a court decision is passed and all legal remedies have been made, and finally, the decision has permanent legal force. The criminal procedure law also regulates the main procedures for the implementation and supervision of the decision.

Based on these thoughts, the writer sees that the purpose of the crime should not focus on finding who the perpetrator can be accused of violating the law, but how to resolve conflicts between parties so that they do not recur because if normative is following the KUHAP guidelines, the same problem will always arise or the criminal offender will never be deterred because it is constantly being blamed which shows no responsive relationship. In responsive law enforcement, law enforcement is not only based on formal law, where the law is enforced only based on rules and laws are only enforced as a guard against every violation or formatted to prevent every violation, but the law must be more progressive. Namely, the law must be seen from the perspective of public justice. ${ }^{12}$ Progressive law correlates with responsive law, where responsive law looks at whether the law-making process involves community participation, and progressive law sees how the attitude of law

10 W.L.G. Lemaire and Van Hattum in Lamintang, Dasar-Dasar Hukum Pidana Indonesia, PT Citra Aditya Bakti, Bandung, 2011, p. 2 \& 9.

11 Andi Sofyan and H. Abd. Asis, Hukum Acara Pidana: Suatu Pengantar, Kencana, Jakarta, 2014, p. 9.

12 Mukhidin, "Hukum Progresif Sebagai Solusi Hukum Yang Mensejahterakan Rakyat", Jurnal Pembaharuan Hukum, Volume 1 Number 3, 2014, p. 4. 
enforcers sees the law. ${ }^{13}$ In criminal law, the principle of opportunity recognizes that the public prosecutor is not obliged to prosecute someone who has committed an offense if, according to his considerations, it will harm the public interest. So in the public interest, someone who commits an offense is not prosecuted..$^{14}$ In addition, the Opportunity Principle is also adopted into Article 35c of Law Number 16 of 2004 concerning the Republic of Indonesia Prosecutor's Office, which clearly states that the opportunistic principle is adhered to in Indonesia, namely "Attorney General can put aside cases based on public interest." According to the author, the opportunity principle is dynamic and in line with progressive law because the public interest always follows the dynamics of society. Progressive law emphasizes that law is an organized entity that aims to lead humans to a just, prosperous life and make humans happy. From this definition, there are two main points of progressive law emphasis; namely, the law is an institution or tool, and the law aims to be just, prosperous and happy.

1. Progressive law is a liberating law; it is this role that the conception of progressive law plays an essential role in liberating legal thought from the shackles of blind and deaf legal positivism against the public's need for justice.

2. Progressive law is an intermediate solution or strategy. Progressive law does not absolutely reject written law. It only gives more portion to the importance of the factor of justice, welfare, people's care as the main objective of the law.

3. Progressive Law as a liberation movement. This legal concept demands that the law always moves in balancing the development of human needs that require legal guarantees and protection. The scope of legal review is what is permissible and not and human behavior and needs. ${ }^{15}$ The existence of progressive law is quite contrary to the concept of normative law coined by Hans Kelsen, who said that judges carry out the peak of the meaning of regulation through a tiered law application. The legal system starts from the constitution, then goes through organic laws, and culminates in a judge's decision. ${ }^{16}$ Progressive law has the following characters:

13 H. Deni Nuryadi, "Teori Hukum Progresif Dan Penerapannya Di Indonesia", Jurnal Ilmiah Hukum, Volume 1 Number 2, 2016, p. 407.

14 Andi Hamzah, Hukum Acara Pidana Indonesia, Sinar Grafika, Jakarta, 2010, p. 17.

15 Hwian Christanto, "Penafsiran Hukum Progresif dalam Perkara Pidana", Jurnal Mimbar Hukum, Volume 23 Number 3, 2011, p. 480.

16 Hans Kelsen, Dasar-Dasar Hukum Normatif, Nusamedia, Jakarta, 2008, p. 2-3. 
1. Whereas the law is not in a stagnant position, but instead it flows like "panta rei" (everything flows).

2. The character of progressive law is that "the law is for man." With this fundamental belief, progressive law positions law not as the center of human circulation but humans who are at the center of the cycle of law.

3. Progressive law refuses to maintain the status quo because of its anxieties about seeking and continually searching for how and where justice is.

4. Progressive law pays excellent attention to justice that lives in the soul of society, "justice that lives in the soul of the nation."17

The concept of progressive law was born out of a revolution over normative law, which seemed rigid. Almost all crimes handled by the Indonesian criminal justice system always end up in prison. Even though the prison is not the best solution in solving crime problems, especially crimes in which the "damage" inflicted on the victim and society can still be repaired or restored so that the damaged condition can be returned to its original state, as well as eliminating the adverse effects of prison because it is someone who is actually not bad when going to prison meets people who have evil intentions and knowledge that is towards the negative which will undoubtedly increase the number of such people. In responding to crimes that are considered to be restorative, There is a punishing paradigm known as restorative justice. The perpetrator is encouraged to repair the harm that has been caused to the victim, his family, and the community. Justice that is based on peace between the perpetrator, the victim, and the community is the primary value of the concept of restorative justice. This principle reminds us that justice and peace are inherently inseparable.

Peace without justice is oppression. Justice without peace is a new form of persecution/pressure. The problem is that the judiciary has been patterned with a retributive justice approach that views crime as a violation committed against the state. This approach focuses on the past, and its purpose is to determine who is to blame and what crimes will be imposed. Restorative justice is an alternative or other way of criminal justice by prioritizing the integration approach of the perpetrator on the one hand and the victim/community on the other hand as a unit to find solutions and return to the pattern of good relations in society. In the context of progressive law, the law is human, not human for law. If the law is for humans, then the methods taken to make humans happy can be tolerated, so that it needs to be developed as part of human efforts to seek justice, including the settlement of

${ }^{17}$ Marilang, "Menimbang Paradigma Keadilan Hukum Progresif Considering The Progressive Legal Justice Paradigm", Jurnal Konstitusi, Volume 14 Number 2, 2017, p. 14. 
criminal cases through non-litigation channels ${ }^{18}$. The forms of sanctions in the restorative justice trial include restitution, mediation of perpetrators and victims, victim services, community restoration, direct services to victims, and restorative fines..$^{19}$ Seeing these things, it is so important to apply the concept of restorative justice because criminal cases arise as a result of conflicts. Ways to eliminate them humanely are involving the perpetrators and victims and the community's presence because the community will be affected if the perpetrators are not deterred from sanctions-normative given by law enforcement agencies and have the potential to repeat related crimes.

Restorative justice is essentially giving punishment to the perpetrator. However, the punishment is educational. It benefits both the perpetrator and the victim as practiced in North America using two approaches: the victimoffender mediation approach that emphasizes compensation. ${ }^{20}$ and in England, namely the recovery (court-based restitutive and reparative measure). ${ }^{21}$ Then universally, the concept of restorative justice itself was discussed at the 11th Five-Annual United Nations Congress in Bangkok in 2005, namely, for the first time restorative justice was adopted as the topic of the congress, namely "Improving Criminal Justice Reform." ${ }^{22}$ It can be seen that every country in the majority of the world has explicitly applied the concept of restorative justice into its criminal law. Indonesia can follow this which the drafting team of the RKUHAP has made a comparative study conducted in several countries. Progressive law views mediation as a very strategic and positive step so that problems can be resolved quickly and can be resolved without litigation involvement. In the end, restorative justice emphasizes solving problems between parties in social relations rather than confronting the perpetrator with government/law enforcement officials.

\section{B. Mediation by Legal Officers in Criminal Case Resolution}

Settlement of criminal cases is always carried out through litigation, which requires mass pressure factors. Mass pressure referred to, according to Halili, is pressure so that the results of the trial are in accordance with the interests of certain groups. So that the proceedings tended to be heavy

\footnotetext{
${ }^{18}$ Satjipto Rahardjo, Penegakan Hukum Progresif, Kompas, Jakarta, 2010, p. 151-152.

19 Barda Nawawi Arief, Mediasi Penal Penyelesaian Perkara di Luar Pengadilan, Pustaka Magister Publisher, Semarang, 2010, p. 157.

20 Ministry of Law and Human Rights, "Naskah Akademik Rancangan Kitab Undang-Undang Hukum Acara Pidana", 2012, p. 4.

21 Op. Cit, Nawawi, p. 156.

22 Anas Yusuf, Implementasi Restorative Justice Dalam Penegakan Hukum oleh Polri, Trisakti University, Jakarta, 2016, p. 201.
} 
because they were directed by certain groups and did not achieve justice. An example is related to the case of religious freedom in the invasion of the Syi'ah community in Sampang as an example. ${ }^{23}$ This case is almost over with a social route through a meeting between ulama, government, and community leaders. However, due to specific mass pressures, this matter was brought to trial, the conflict between the factions involved had widened. It shows a reflection of the ongoing litigation settlement. History proves that nonlitigation resolution is rarely an option and shows that there were only 21 cases of religious blasphemy that were resolved non-litigation out of a total of 97 cases of blasphemy. ${ }^{24}$ The state should clearly protect its citizens in adhering to and living their religion as stated in our constitution. Indonesia has regulated mediation which can be seen in Law no. 30 of 1999 concerning Arbitration and Alternative Dispute Resolution and Supreme Court Regulation Number 1 of 2016 concerning Mediation Procedures in Courts. According to Article 1 number 1 Perma 1/2016, mediation is a way of resolving disputes through the negotiation process to obtain an agreement between the parties with the assistance of a mediator.

Dispute resolution through non-litigation in the form of mediation has the following advantages:

1. To reduce congestion and court congestion in the courts to reduce the litigation process is often lengthy and costly and often yields unsatisfactory results;

2. To increase community involvement (legal decentralization) or empower the disputing parties in the dispute resolution process;

3. To expedite the path of justice (access to justice) in society;

4. To provide an opportunity for the achievement of dispute resolution that results in decisions that are acceptable to all parties so that the parties do not seek appeal and cassation;

5. Settlement of cases is faster and of lower cost;

6. Are closed / confidential (confidential);

7. The higher level of possibility to implement the agreement so that the relationship between the disputing parties in the future is still possible to be well established;

${ }^{23}$ In 2012, as many as 20 Shia children riding in a minibus were stopped by 30 motorbikes. They were then forced to return home and prohibited from studying at the Shia Islamic boarding school outside Sampang, and there was an attack. Tempo, "Kronologi Penyerangan Warga Syiah di Sampang", Tempo, August 27, 2012, accessed from https://nasional.tempo.co/read/425697/kronologi-peny Serangan-warga-syiah-disampang/full\&view $=$ ok.

24 Tempo, "Setara: Kasus Penistaan Agama Cocok Diselesaikan Tanpa Pengadilan", Tempo, May 12, 2017, accessed from https://nasional.tempo.co/read/874526/setara-kasus-penistaan-agama-cocokdiselesai-tanpa- court $/$ full \& view $=$ ok. 
8. Reducing the prevalence of "dirty play" in court. ${ }^{25}$

In general, criminal cases that usually use non-litigation through mediation are cases regulated in the provisions of article 310 of the Criminal Code (defamation/defamation), Article 311 of the Criminal Code (slander), Article 351 of the Criminal Code (persecution), article 352 paragraph (1). KUHP (light maltreatment), Article 359 KUHP (due to negligence causing the death of a person), article 372 KUHP (embezzlement), Article 378 KUHP (fraud), article $285 \mathrm{KUHP}$ (adultery), article $332 \mathrm{KUHP}$ (running an underage girl), and 367 paragraph (2) of the Criminal Code (theft committed by family members), as well as Article 156a of the Criminal Code (Blasphemy of Religion), as well as criminal offenses that are regulated outside the Criminal Code but in-laws such as Law no. 15 of 2001 concerning Marks related to trademark falsification, domestic violence (Law Number 23 of 2004 concerning the Elimination of Domestic Violence).

Justice in criminal procedural law is a process from the time an investigation is carried out until a court decision has the status of res judicata or has a permanent legal force, which in detail consists of the occurrence of legal events, investigations, investigations, pre-trial, pre-prosecution, trial, the verdict (reading of the indictment, objections/exceptions, response to exceptions, interlocutory verdicts, evidence, lawsuits, defenses, duplicates), legal remedies, execution, supervision, and observation. ${ }^{26}$ Seeing this flow, mediation can be used at the investigation stage by investigations before the trial. Namely, the investigation stage at the investigation stage as the investigator's authority, namely the police, with their discretion as the foremost legal apparatus can stop investigations in the Criminal Procedure Code and should be able to apply restorative justice. Article 18 of Law Number 2 of 2002 concerning the State Police of the Republic of Indonesia states:

"(1) In the public interest, officials of the State Police of the Republic of Indonesia can act according to their judgment in carrying out their duties and authorities.

(2) The implementation of the provisions as referred to in paragraph (1) can only be carried out in an indispensable condition with due observance of statutory regulations, as well as the Professional Code of Ethics for the State Police of the Republic of Indonesia."

The police need to use discretion because they are law enforcement officers and order keepers who are tasked with maintaining peace and order

\footnotetext{
25 Kamaruddin, "Mediasi Dalam Pandangan Hukum Progresif Suatu Alternatif Penyelesaian Konflik Keluarga", Jurnal Al-'Ad, Volume 11 Number 2, 2018, p. 14.

26 Op. Cit, Anas Yusuf, p. 30.
} 
in general. The police cannot turn a blind ear to the changes that are taking place and have not been accommodated in the great flow of life. Formal formats have not always been able to accommodate such large waves of change, so that there is still a wide gap between the slogan of reform and the reality of government behavior. The ideas of change have not yet been able to enter the mainstream of life, so it is the discretionary task of the police to guard these ideas. To transition from authoritarian rule to democratic government, the police need to be more creative in carrying out their mission of protecting, nurturing, and serving the people. ${ }^{27}$ So that with this discretion, the police can apply non-litigation solutions to criminal cases as mentioned above through a mediation mechanism based on discretion. However, there has been no solid legal umbrella regarding the legal arrangements for mediation in the criminal procedure law until now. In this case, it is in line with the implementation of Restorative Justice in a settlement out of court or known as Alternative Dispute Resolution (ADR), one of which is mediation. ${ }^{28}$

In practice, mediation itself can reconcile criminal cases such as theft, humiliation, etc. However, mediation also often has problems in the field, such as being considered "lip service" if, in the end, it will be criminalized so that the seriousness of the legal apparatus is important in implementing the mediation. Mediation involves the existence of a third party (either individually or in the form of an independent institution) who is neutral and impartial, who will function as a mediator. ${ }^{29}$ Mediation in Indonesia is similar to the plea bargaining system in the United States. This method uses methods in civil law to resolve criminal cases. The difference is if, in the plea bargaining system, the one who negotiates is the public prosecutor (prosecutor) with the perpetrator of the crime or legal advisor and does not involve the victim, while in settlement of cases through non-litigation channels, there is no role for the public prosecutor. The main factor is the perpetrator and the victim with the help of one or several persons if necessary. Settlement of this case can also be done within the Criminal Justice System (hereinafter as SPP) framework, which only reaches the police level and outside the SPP framework if the case has not been reported to the police. The plea bargaining system only facilitates the settlement of criminal cases through litigation and does not abolish or stop the criminal justice process. Meanwhile, the settlement of criminal cases through non-litigation channels can abolish or stop the criminal justice process up to the police level. So the criminal justice process was not continued after an agreement was reached

27 Satjipto Rahardjo, Sosiologi Hukum, Genta Publishing, Yogyakarta, 2010, p. 108-109.

28 Op. Cit, Anas Yusuf, p. 15.

29 Gunawan Widjaja, Seri Hukum Bisnis: Alternatif Penyelesaian Sengketa, PT Raja Grafindo Persada, Jakarta, 2002, p. 91. 
between the perpetrator and the victim regarding the form of compensation to be provided. ${ }^{30}$ The principle of win-win solution in mediation is suitable for adoption as an alternative to the settlement of criminal cases committed by corporations/individuals, given the concept of the new Draft Criminal Code (hereinafter as RKUHP) that one of the objectives of punishment is to resolve conflicts caused by criminal acts, restore balance, and bring a sense of peace in society and relieve the guilt of the convicted person. ${ }^{31}$ The differences between civil mediation and criminal mediation (penal) are:

1. Civil mediation focuses on problems and agreements, while penal mediation focuses on dialogue and relationships.

2. The role of the mediator in civil mediation is to direct and guide the parties to reach a satisfactory agreement, while criminal mediation is to prepare victims and perpetrators to have realistic expectations and feel safe enough to have a direct dialogue.

3. A written agreement on civil mediation is the main goal to be achieved due to mediation, while in criminal mediation, it is a secondary target. The primary one is dialogue and mutual help. ${ }^{32}$

The concept of mediation in other countries in criminal law can also be seen in France as stipulated in Law 4 January 1993 amending Article 41 of the Criminal Procedure Code (hereinafter as CCP-Code of Criminal Procedure), which was developed based on Law 18 December 1998 and Law 9 June 1999, namely the public prosecutor can mediate between the perpetrator and the victim, before making a decision, whether someone should be prosecuted. Then the essence of Article 41 of the CCP regulates that the public prosecutor can conduct penal mediation (with the consent of the victim and the perpetrator) if it is deemed to be an action that can repair the losses suffered by the victim, end the distress, and help repair (rehabilitate) the perpetrator. If the mediation is not successful, the prosecution will only be carried out, but if it is successful, the prosecution is terminated (article 41 and articles 41-2 CCPCode of Criminal Procedure). For certain crimes, Article 41-2 of the CCP allows the general prosecutor to ask the perpetrator to compensate the victim (mediating penalties) instead of imposing a fine, revoking a driver's license, or ordering alternative sanctions in the form of social work punishment for 60 hours. The implementation of this penal mediation eliminates prosecution.

30 Agus Raharjo, "Mediasi sebagai basis dalam penyelesaian perkara pidana", Jurnal Mimbar Hukum, Volume 20 Number 1, 2008, p. 104.

31 Beja Suryo Hadi Purnomo, "Kedudukan Mediasi Penal Dalam Sistem Peradilan Di Indonesia", Jurnal Ilmiah Ilmu Sosial, Volume 4 Number 2, 2018, p. 192.

32 Fatahillah A. Syukur, Mediasi Perkara KDRT (Kekerasan Dalam Rumah Tangga): Teori dan Praktek di Pengadilan Indonesia, Publisher Mandar Maju, Bandung, 2001, p. 68. 
Certain criminal acts are referred to in Article 41-2 CCP. ${ }^{33}$ Indonesia should be able to emulate the application of restorative justice in these countries because it can be seen as the result of legal progress.

\section{Penal Mediation Mechanism in the Draft Criminal Procedure Code}

Criminal cases that are resolved through mediation are also known as penal mediation. Penal mediation itself can be interpreted as the settlement of a criminal case through a meeting between the victim and the perpetrator of a criminal act to solve the problem by agreeing to the parties (win-win solution). ${ }^{34}$ Non-litigation settlement in criminal procedural law recognizes penal mediation, which is different from mediation in civil law. According to Mudzakkir, several categorizations as benchmarks and scope for cases that can be resolved out of court through Penal Mediation are as follows:

1. Violation of the criminal law is subject to a fine as a criminal threat, and the offender has paid the fine (Article 80 of the Criminal Code).

2. Violation of the criminal law is included in the category of "offense," not "crime," which is only punishable by a fine.

3. Violations of criminal law include criminal acts in the field of administrative law that place criminal sanctions as ultimum remedium.

4. These criminal law violations are categorized as light / all-too-light, and law enforcement officials use their powers to exercise discretion.

5. Ordinary criminal law violations are terminated or not processed in court by the Attorney General following their legal authority.

6. Violations of criminal law are included in the category of violations of customary criminal law which are resolved through customary institutions. ${ }^{35}$

Penal mediation is in line with the application of restorative justice, seeing one of the efforts to implement restorative justice that can be carried out by legal officers, namely the police, in maximizing settlement by using the Penal mediation mechanism. As the primary guardian of the criminal justice system, the police can resolve these cases with the authority that is discretion in resolving a criminal case for consumer protection. ${ }^{36}$ The universal penal mediation model is:

${ }^{33}$ National Law Development Agency of the Ministry of Law and Human Rights of the Republic of Indonesia, Pengkajian Hukum tentang Penerapan Restorative Justice dalam Penyelesaian Tindak Pidana yang dilakukan oleh anak-anak, Jakarta, 2013, p. 69.

34 Reyner \& Dian Adriawan Daeng Tawang, “Alternatif Mediasi Penal Dalam Sistem Peradilan Pidana di Indonesia", Jurnal Hukum Adigama, Volume 1 Number 2, 2018, p. 22.

35 I Made Agus Mahendra Iswara, "Mediasi Penal Penerapan Nilai-Nilai Restoratif Justice dalam Penyelesaian Tindak Pidana Adat Bali", Thesis, Postgraduate Program, Faculty of Law, University of Indonesia, 2013, p. 55-56.

${ }^{36}$ Ibid, p. 208. 
1. Informal mediation

This model is implemented by criminal justice personnel in their regular duties, namely that the Public Prosecutor can carry it out by inviting the parties to carry out an informal settlement with the aim of not continuing the prosecution if an agreement is reached; can be done by a social worker or a probation officer, by a police officer, or by a judge.

2. Traditional village or tribal moots

In this model, the whole society meets to solve criminal conflicts among its citizens. This model predates western law and has inspired most modern mediation programs.

3. Victim-offender mediation

This model involves various parties who meet in the presence of a designated mediator, which can come from a formal official, an independent mediator, or a combination and can be held at every stage of the criminal case examination process.

4. Reparation negotiation programs

This model is solely for estimating/assessing the compensation or reparation paid by the perpetrator to the victim, who is usually done during the examination in court. Like a criminal offender, he can be subject to a work program in order to save money to pay for compensation.

5. Community panels or courts

This model is a program to deflect criminal cases from prosecution or justice into more flexible and informal community procedures and often involve elements of mediation or negotiation.

6. Family and community group conferences

This model has been developed in Australia and New Zealand, which involves community participation in the criminal justice system. This model involves victims and perpetrators of criminal acts and the families of the perpetrators and other members of the community, certain officials (such as police and child judges), and victim supporters. ${ }^{37}$

The application of the penal mediation model as part of the criminal justice system (SPP) process can be made as follows:

1. Penal mediation at the criminal investigation stage is the initial stage of the criminal justice process. At this stage, investigators can continue or discontinue criminal acts into the criminal justice process.

\footnotetext{
${ }^{37}$ Ibid, National Law Development Agency of the Ministry of Law and Human Rights of the Republic of Indonesia, p. 13-15.
} 
2. Penal mediation at the prosecution stage, after a delegation from investigator to the public prosecutor. In this stage, the public prosecutor is not supposed to immediately forward the criminal offense to the court but rather encourages the parties to reconcile. The public prosecutor can immediately stop the prosecution if there has been a settlement outside the criminal justice system process or through a settlement of typical / village institutions.

3. Penal mediation at the court hearing examination stage, penal mediation is carried out at this stage after the case is transferred to court by the public prosecutor. In this stage of mediation, as in civil cases, judges offer an alternative to the settlement of criminal cases by way of conciliation to the parties, namely the perpetrator of the crime and the victim, before an examination process is carried out in front of a court hearing by looking at the criteria for a criminal act committed by the defendant. If this mediation reaches an agreement, the results can be used as an excuse to abolish committing crimes for the perpetrators of criminal acts. The mediator at this stage can be carried out by a judge or a mediator from outside the court.

4. Penal mediation at the stage of the perpetrator carrying out imprisonment, at this stage the penal mediation is carried out in the form of a reparation negotiation program which focuses on the payment of compensation from the perpetrator to the victim, or in the form of victim offender-mediation, which focuses both on the concept of reconciliation and on the compensation payment agreement. Loss to the victim. In this case, it serves as an excuse to abolish the authority to carry out part of the crime if the perpetrator has carried out part of the crime. ${ }^{38}$

However, the implementation of penal mediation that starts from the police investigation stage has obstacles that often become obstacles in its application. Factors that hinder the running of Penal Mediation through the Restorative Justice approach as an effort to minimize overcapacity starting from the police investigation stage include:

1. The statutory factor, namely the absence of a law regulating the efforts that must be taken in the event of a rejection of peace by the victim or the victim's family.

2. Law enforcement factors, namely in terms of quantity, the number of members is still limited in handling criminal acts. There is still a lack of

${ }^{38}$ Rudini Hasyim Rado, Barda Nawawi Arief, \& Eko Soponyono, "Kebijakan Mediasi Penal Terhadap Penyelesaian Konflik Sara Di Kepulauan Kei Dalam Upaya Pembaharuan Hukum Pidana Nasional", Jurnal Law Reform, Volume 12 Number 2, 2016, p. 274-275. 
knowledge and skills of investigators in implementing peace in settlement of criminal acts in quality.

3. Community factors, especially victims and victims' families, reject peace and want the perpetrators of criminal acts to be processed legally as perpetrators of criminal acts. ${ }^{39}$

The existence of penal mediation can then be seen in the Letter of the Chief of Police No. Pol: B / 3022 / XII / 2009 / SDEOPS dated December 14, 2009, concerning case Handling through Alternative Dispute Resolution (ADR), which emphasizes the settlement of criminal cases using ADR as long as it is agreed by the parties in litigation. Considering that the Kapolri Letter is internal and not a general binding statutory rule, it is just that. Then it can be seen in the Copyright case as regulated in Article 95 paragraph (4) of Law no. 28 of 2014 concerning Copyright and Criminalization in Patents as regulated in Article 154 of Law no. 13 of 2016 concerning Patents. Law on Copyright Law on Patents Article 95 paragraph (4): In addition to violations of Copyright and Related Rights in the form of Piracy, as long as the disputing parties are known to exist and are in the territory of the Unitary State of the Republic of Indonesia, they must first seek dispute resolution through mediation before making criminal charges. Article 154: In the event of a criminal charge against a simple Patent or Patent infringement, the parties must first settle it through mediation. ${ }^{40}$ So that several principles can be drawn, namely:

1. Acceptance of penal mediation in the positive legal system has so far been debated among experts whether mediation can solve criminal cases.

2. Penal mediation is applied to criminal offenses that are not categorized as severe or serious crimes in their respective fields. For copyright cases, penal mediation cannot be applied to piracy cases, such as DVD copying. As for patents, it is only applied to cases of criminal infringement for simple patents.

3. Penal mediation is applied to criminal offenses that fall under the complaint offense category.

\footnotetext{
${ }^{39}$ July Esther, Bintang ME Naibaho, \& Bintang Christine, "Mediasi Penal Dalam Penanganan Pelaku Tindak Pidana Sebagai Upaya Meminimalisir Kelebihan Hunian Di Lembaga Pemasyarakatan", Jurnal Magister Hukum Program Pascasarjana Universitas HKBP Nommensen, Volume 1 Number 1, 2020, p. 35.

${ }^{40}$ Hukum Online, "Ini Kasus-kasus Pidana yang Bisa Dimediasi di Indonesia", Hukum Online, 6 November 2018, accessed from https://www.hukumonline.com/berita/baca/lt5be1858164328/inikasus-kasus-pidana-yang-bisa-dimediasi-di-indonesia?page=3.
} 
Then also, penal mediation can be applied in criminal cases of copyright and patent is a complaint offense as specified in Article 120 of Law Number 28 of 2014 concerning Copyright and Article 165 of Law No. 13 of 2016 concerning Patents (except for criminal infringement of patents that causes human death, health problems and the environment). The discussion and settlement of peace between offenders and victims in intellectual property are not without reason because basically, the law between the creator/inventor and the perpetrator is a private to a personal relationship. Victims of intellectual property violations prefer to get compensation rather than imprison the victim as an act of restoring their rights. Therefore, dispute resolution through penal mediation in criminal intellectual property infringement has an intersection with the idea of restorative justice. As understood, restorative justice is a concept of justice that puts the victim back in the original state rather than punishing the perpetrator of a criminal act. So it can be said that restorative justice is a concept that reorganizes to achieve a fairer criminal system. ${ }^{41}$ Then after child criminal cases as regulated in Law no. 11 of 2012 concerning the Juvenile Criminal Justice System, children who commit criminal acts are not mutatis mutandis brought in criminal justice but are allowed to be resolved outside of court proceedings. This model is referred to as diversion. In short, the paradigm of criminal justice, especially in juvenile justice, has shifted to a restorative direction. In settlement of child cases, efforts are also made so that the perpetrator and his family and the victim and his family can sit together to discuss the resolution of the problem, including restoration to the victim. This provision is a form of penal mediation even though the context is different. Article 7 paragraph (1) of the SPP Law requires diversion at the level of investigation, prosecution, and examination of cases of children at the District Court specifically for criminal acts of children which are punishable by imprisonment of less than 7 (seven) years and are not a repetition of a criminal act (recidivist) so that it changes the direction of the retributive justice approach to a restorative justice approach. ${ }^{42}$ Implementing the types of cases above that fulfill criminal offenses shows that penal mediation as a concept of restorative justice needs to be integrated and adopted in the RKUHAP.

${ }^{41}$ Tri Harnowo, "Eksistensi Mediasi Penal dalam Penyelesaian Pelanggaran Pidana Kekayaan Intelektual", Hukum Online ", Hukum Online, August 3, 2018, accessed from https://www.hukumonline.com/berita/baca/lt5b63f97258b43/eksistensi-mediasi-penal-dalampenyelesaian-pelanggaran-pidana-kekayaan-intelektual-oleh--tri-harnowo/.

42 ASH, "Mediasi Perkara Pidana Anak, Begini Filosofinya", Hukum Online, February 12, 2016, accessed from https://www.hukumonline.com/berita/baca/lt56bd60dd5c226/mediasi-perkarapidana-anak--begini-filosofinya/. 
Institute for Criminal Justice Reform (ICJR) has mapped six issues in the current Criminal Procedure Code that are important to pay attention to, namely the institutional structure and inconsistent granting of authority to law enforcement officials, the absence of an effective judicial oversight system, the lack of efforts to provide legal assistance and provide information related to rights. the rights of suspects/defendants/convicts, the excessive use of forced detention, the absence of a mechanism to prevent the practice of torture, and an unclear mechanism for the protection of crime victims ${ }^{43}$. The issues presented are a situation that does not reflect justice in the current criminal law system. It is necessary to make changes, one of which is through the preparation of the concept of penal mediation, which emphasizes restorative justice in the RKUHAP. The formation of law is considered aspirational if, in the process, it takes into account the aspirations of the community. The public has the right to provide input orally and/or in writing to form laws and regulations. As stipulated in the DPR RI Regulation, many obligations of the DPR have been contained. To guarantee the right to public participation, it can be identified and assessed from several things, namely the preparation and determination of the National Legislation Program, drafting and discussion of draft laws, discussion of the bill on the state budget, supervision of the implementation of laws. ${ }^{44}$ Formally, Article 96 of Law no. 12 of 2011 concerning the Formation of Invitation Laws has provided guarantees for citizens to be involved in the process of drafting laws and regulations in the legislature. The author hopes that this paper can be part of these aspirations. BM Taverne once said, "Give me a good commissioner judge, prosecutor, and police. I can work well even with the bad Criminal Procedure Code."45 These words are very profound for the current drafting of the RKUHAP. It is significant for the involvement of our legal apparatus to pay attention to certainty and justice wisely, especially in this case, immediately apply the concept of restorative justice, which can be implemented in mediation penal in the Indonesian criminal law system through the RKUHAP.

\section{CONCLUSION}

To realize restorative justice, legal officers must see the progressive application of statutory provisions not normative so far because this does not

${ }^{43}$ Institute for Criminal Justice Reform, "ICJR Ingatkan Kembali Urgensi Pembahasan RKUHP, RKUHAP dan Revisi UU Narkotika", ICJR, 28 November 2019, accessed from https:/icjr.or.id/icjringatkan-kembali-urgensi-pembahasan-rkuhp-rkuhap-dan-revisi-uu-narkotika/. Joko Riskiyono, "Partisipasi Masyarakat Dalam Pembentukan Perundang-Undangan Untuk Mewujudkan Kesejahteraan", Jurnal Aspirasi 1, Volume 6 Number 2, 2015, p. 168.

${ }^{45}$ Op. Cit, Anas Yusuf, p. 31. 
show any progress in the development of existing criminal procedural law. We can see that prisons are getting full when they cannot accommodate anymore, which causes the problem of new returns and justice is still far away for everyone and the inability to achieve the objectives of the criminal law itself for peace, security, and prosperity. Therefore, as long as there is no legal umbrella for the form of restorative justice, a penal mediation mechanism can be used in handling certain criminal cases. When it is proven that other countries apply restorative justice to their constitution, Indonesian people uphold the culture of mutual forgiveness according to the teachings of Pancasila in everyday life. The concept of restorative justice is part of the noble values of the Indonesian nation is applied in the RKUHAP. The recommendation that the author can formulate is that there needs to be an increase in the education and training of police and judges regarding the importance of the concept of restorative justice continuously so that in the future it will give birth to law enforcers who are critical and progressive following the times exploring the values that exist in a society that is continuously developing in upholding the law. Sure and fair, prioritizing the mediation mechanism at the stage of investigation and imposition of criminal sanctions by judges who prioritize restoration justice for the perpetrator so that later they can solve prison problems that are always overcapacity and the provisions of restorative justice can be applied in the RKUHAP in the explanation section for terminating investigations, there is a mediation penalty mechanism, where there are also opportunities for other matters. The RKUHAP is very important to encourage the implementation of a criminal justice system that is accountable, open, integrative, and guarantees the fulfillment of the rights of suspects, defendants, witnesses, and victims of crime so that a balance of protection is created between interests, namely the interests of the state, the interests of the community.

\section{DECLARATION OF CONFLICTING INTEREST}

None

\section{FUNDING INFORMATION}

None

\section{ACKNOWLEDGEMENT}

My gratitude goes to my family, colleagues at SMA Van Lith Muntilan, Faculty of Law, University of Indonesia, and the Cabinet Secretariat of the Republic of Indonesia, who has always supported me to complete this research article well. 


\section{REFERENCES}

Arief, B. N. (2010). Mediasi Penal Penyelesaian Perkara di Luar Pengadilan. Semarang: Publisher Pustaka Magister.

Arpin \& Haritsa. (2018). Penyelesaian Tindak Pidana Melalui Mediasi Penal Oleh Masyarakat Desa Di Kabupaten Gorontalo. Jurnal Jurisprudentie, 5 (2).

ASH. (February, 2016). "Mediasi Perkara Pidana Anak, Begini Filosofinya", Hukum Online, February 12, 2016, accessed from https://www.hukumonline.com/berita/baca/lt56bd60dd5c226/mediasiperkara-pidana-anak--begini-filosofinya/.

Bachtiar, A. (November, 2018). "Mengapa Belanda Kekurangan Narapidana", Kumparan, November 9, 2018, accessed from https://kumparan.com/absal-bachtiar/mengapa-belanda-kekurangnarapidana-1541777778863219334.

Christanto, H. (2011). Penafsiran Hukum Progresif dalam Perkara Pidana. Jurnal Mimbar Hukum, 23 (3), 480.

Directory of Supreme Court Decisions, accessed from https://putusan3.mahkamahagung.go.id/dirdir/index/kategories/pidana -umum-.

Esther, J., Naibaho, B. M. E., \& Christine, B. (2020). Mediasi Penal Dalam Penanganan Pelaku Tindak Pidana Sebagai Upaya Meminimalisir Kelebihan Hunian Di Lembaga Pemasyarakatan. Jurnal Magister Hukum Program Pascasarjana Universitas HKBP Nommensen, 1 (1), 35.

Hamzah, A. (2010). Hukum Acara Pidana Indonesia. Jakarta: Sinar Grafika.

Harnowo, T. (August, 2020). "Eksistensi Mediasi Penal dalam Penyelesaian Pelanggaran Pidana Kekayaan Intelektual", Hukum Online, August 3, 2018, accessed from https://www.hukumonline.com/berita/baca/lt5b63f97258b43/eksistenmediasi-penal-dalam-penyel settlement-pelanggaran-pidana -wealthintellectuals-by - tri-harnowo /.

Hukum Online. (November, 2018). "Ini Kasus-kasus Pidana yang Bisa Dimediasi di Indonesia", Hukum Online, November 6, 2018, accessed from https://www.hukumonline.com/berita/baca/lt5be1858164328/inikasus-kasus-pidana-yang-bisa- mediated-in-indonesia? page $=3$.

Institute for Criminal Justice Reform. (November, 2018). "ICJR Ingatkan Kembali Urgensi Pembahasan RKUHP, RKUHAP dan Revisi UU Narkotika", ICJR, November 28, 2019, accessed from https://icjr.or.id/icjr- remind-k Kembali-urgensi-pembahasan-rkuhprkuhap-dan-revisi -uu-narcotics /. 
Iswara, I. M. A. M. (2013). Mediasi Penal Penerapan Nilai-Nilai Restoratif Justice dalam Penyelesaian Tindak Pidana Adat Bali. Tesis, Program Pascasarjana Fakultas Hukum Universitas Indonesia, 55-56.

Kamaruddin. (2018). Mediasi Dalam Pandangan Hukum Progresif Suatu Alternatif Penyelesaian Konflik Keluarga. Jurnal Al-'Ad, 11 (2), 14.

Kelsen, H. (2008). Dasar-Dasar Hukum Normatif. Jakarta: Nusamedia.

Lamintang. (2011). Dasar-Dasar Hukum Pidana Indonesia. Bandung: PT Citra Aditya Bakti.

Latifah, M. (2019). Overcrowded Pada Rumah Tahanan Dan Lembaga Pemasyarakatan Di Indonesia: Dampak Dan Solusinya, Info Singkat. Pusat Penelitian Badan Keahlian DPR RI, XI (10 / II / Puslit / May / 2019), 2.

Marilang. (2017). Menimbang Paradigma Keadilan Hukum Progresif Considering The Progressive Legal Justice Paradigm. Jurnal Konstitusi, $14(2), 14$.

Mukhidin. (2014). Hukum Progresif Sebagai Solusi Hukum Yang Mensejahterakan Rakyat. Jurnal Pembaharuan Hukum, 1 (3), 4.

Ministry of Law and Human Rights. (2012). Naskah Akademik Rancangan Kitab Undang-Undang Hukum Acara Pidana, 4. http://ditjenpp.kemenkumham.go.id/.

Ministry of Law and Human Rights National Legal Development Agency. (2013). Pengkajian Hukum tentang Penerapan Restorative Justice dalam Penyelesaian Tindak Pidana yang dilakukan oleh anak-anak. Jakarta.

Nuryadi, H. D. (2016). Teori Hukum Progresif Dan Penerapannya Di Indonesia. Jurnal Ilmiah Hukum, 1 (2), 407.

Purnomo, B. S. H. (2018). Kedudukan Mediasi Penal Dalam Sistem Peradilan Di Indonesia. Jurnal Ilmiah Ilmu Sosial, 4 (2), 192.

Rado, R. H., Arief, B. N., \& Soponyono, E. (2016). Kebijakan Mediasi Penal Terhadap Penyelesaian Konflik Sara Di Kepulauan Kei Dalam Upaya Pembaharuan Hukum Pidana Nasional. Jurnal Law Reform, 12 (2), 274275.

Raharjo, A. (2008). Mediasi Sebagai Basis Dalam Penyelesaian Perkara Pidana. Jurnal Mimbar Hukum, 20 (1) 104.

Rahardjo, S. (2010). Sosiologi Hukum. Yogyakarta: Genta Publishing. Rahardjo, S. (2010). Penegakan Hukum Progresif. Jakarta: Kompas.

Reyner \& Tawang, D. A. D. (2018). Alternatif Mediasi Penal Dalam Sistem Peradilan Pidana Di Indonesia. Jurnal Hukum Adigama, 1 (2), 22.

Riskiyono, J. (2015). Partisipasi Masyarakat Dalam Pembentukan PerundangUndangan Untuk Mewujudkan Kesejahteraan. Jurnal Aspirasi, 6 (2), 168.

Santoso, A. (April, 2020). "27 Napi Berulah Lagi Setelah Dibebaskan, Kabareskrim: Sanksi Lebih Berat", Detik, April 21, 2020, accessed from 
https://news.detik.com/berita/d-4984907/27-napi-berulah-lagi- afterdibebas -kabareskrim-sanctions-more-severe / 2.

Santoso, P. (2020). Diskresi Kepolisian Melalui Mediasi Penal (Studi Kasus di Polsek Galur, Kulonprogo). Jurnal Penegakan Hukum dan Keadilan, 1 (2), 102.

Situmorang, V. H. (2019). Lembaga Pemasyarakatan Sebagai Bagian Dari Penegakan Hukum (Correctional Institution as Part of Law Enforcement). Jurnal Pusat Pengkajian dan Pengembangan Kebijakan Badan Penelitian dan Pengembangan Hukum dan HAM Kementerian Hukum dan HAM RI, 13 (1), 90.

Sofyan, A. \& Asis, HA (2014). Hukum Acara Pidana: Suatu Pengantar. Jakarta: Golden.

Sudaryono, I. M. \& Kuswardani. (2012). Model Penyelesaian Secara Alternatif Dalam Peradilan Pidana (Studi Khusus Terhadap Model Penyelesaian Perkara Pidana Oleh Lembaga Kepolisian). Jurnal Penelitian Humaniora, $13(1), 62-73$.

Syukur, F. A. (2001). Mediasi Perkara KDRT (Kekerasan Dalam Rumah Tangga): Teori dan Praktek di Pengadilan Indonesia. Bandung: Mandar Maju Publisher.

Tempo. (August, 2012). "Kronologi Penyerangan Warga Syiah di Sampang", Tempo, August 27, 2012, accessed from https://nasional.tempo.co/read/425697/kronologi-penyerang-wargasyiah-di-sampang/full\&view $=$ ok.

Tempo. (May, 2017). "Setara: Kasus Penistaan Agama Cocok Diselesaikan Tanpa Pengadilan", Tempo, May 12, 2017, accessed from https://nasional.tempo.co/read/874526/setara-kasus-penistaan-agamacocok-diselesai-tanpa-pengadilan/ full \& view $=$ ok.

The Republic of Indonesia. (1999). Law Number 30 of 1999 concerning Arbitration and Alternative Dispute Resolution. State Gazette Number 138 of 1999, Supplement to the State Gazette Number 3872.

The Republic of Indonesia. (2014). Law Number 28 of 2014 concerning Copyright. State Gazette Number 266 of 2014, Supplement to State Institutions Number 5599.

The Republic of Indonesia. (2002). Law Number 2 of 2002 concerning the Indonesian National Police. State Gazette Number 2 of 2002, Supplement to the State Gazette Number 4168.

The Republic of Indonesia. (2004). Law Number 16 of 2004 concerning the Republic of Indonesia Attorney General's Office. State Gazette Number 67 of 2004, Supplement to State Institution Number 4401. 
The Republic of Indonesia. (1981). Law Number 8 of 1981 concerning the Criminal Procedure Code. State Gazette Number 76 of 1981, Supplement to the State Gazette Number 3209.

The Republic of Indonesia. (2016). Law Number 13 of 2016 concerning Patents. State Gazette Number 176 of 2016, Supplement to State Institution Number 5922.

The Republic of Indonesia. (2011). Law Number 12 of 2011 concerning the Formation of Legislative Regulations. State Gazette Number 82 of 2011, Supplement to the State Gazette Number 5234.

The Republic of Indonesia. (2016). Supreme Court Regulation Number 1 of 2016 concerning Mediation Procedures in Courts. State Gazette Number 175 of 2016.

The Republic of Indonesia. (2012). Law Number 11 of 2012 concerning the Criminal Justice System for Children. State Gazette 153 of 2012, Supplement to the State Gazette Number 5332.

Utrecht. (1994). Hukum Pidana I. Surabaya: Pustaka Tinta Mas.

Widjaja, G. (2002). Seri Hukum Bisnis: Alternatif Penyelesaian Sengketa. Jakarta: PT Raja Grafindo Persada.

Yusuf, A. (2016). Implementation of Restorative Justice in Law Enforcement by the Police. Jakarta: Trisakti University. 


\section{ABOUT AUTHOR(S)}

Emmanuel Ariananto Waluyo Adi, S.H., born in Jakarta in 1996. Graduated from the Faculty of Law, University of Indonesia in 2018, while actively studying at the Student Executive Board, was awarded 2nd place in the UI Batik Design Competition and 2nd Place in the UI Art War Comic Strip Contest, having internship experience at the Attorney General's Office of the Republic of Indonesia Indonesia, PT Pertamina Geothermal Energy, the Indonesian Legal Aid Foundation, and several lawyers' offices and joined as volunteers for the Indonesian Red Cross in East Bekasi district and Bekasi English Club activities. The author has been sworn in as a Civil Servant in 2019 at the Cabinet Secretariat of the Republic of Indonesia who currently works as a Legal Analyst for the Environment at the Deputy for Maritime Affairs and Investment. The author has made several publications, namely the Journal of Legal Reflection Volume 5 Number 1. 


\section{LEGAL ADAGE}

\section{DORMIUNT ALIQUANDO LEGES, NUNQUAM MORIUNTUR}

\section{Laws Sometimes Sleep But Never Die}

